\title{
Optimal dose of phenylephrine infusion for management of maternal hypotension under spinal anaesthesia for caesarean delivery
}

\author{
NM Srinivasan ${ }^{1 *}$, NM Gopalswamy ${ }^{2}$ \\ Associate Professor ${ }^{l}$, Resident ${ }^{2}$,Employees' State Insurance Medical College, Bangalore, India \\ Corresponding author: natarajms23@gmail.com
}

\begin{abstract}
Phenylephrine is the drug presently recommended for prevention of maternal hypotension during caesarean section. The optimal infusion dose is still undetermined. We tried to determine the optimal infusion dose of phenylephrine to prevent maternal hypotension. After Institutional Ethical committee approval, consenting one hundred ASA physical status I or II parturients for elective caesarean delivery were included randomized into 4 groups of 25 each by picking lots. Group P25, P50, P75 and P100 received phenylephrine infusion in concentrations of $25,50,75$ and $100 \mu \mathrm{g} / \mathrm{min}$ respectively. After administering spinal anaesthesia a infusion was started as per group allocation. 20\% change in baseline mean blood pressure was taken for intervention. Hypotension was treated with $50 \mu \mathrm{g}$ phenylephrine bolus, bradycardia treated with atropine $0.6 \mathrm{mg}$. Hypertension treated by stopping the infusion. Neonatal Apgar at 1 and 5 minutes and base deficit in cord blood was assessed. Demographic, anaesthetic and surgical characteristics were comparable. $25 \%$ of patients in group P25 had hypotension requiring bolus phenylephrine dose. 40\% in group P75 and 55\% in group P100 had hypertension requiring infusion to be stopped. 6 patients in group P75 and 9 patients in group P100 required atropine to treat bradycardia. Neonatal outcome were comparable in 4 groups.

Conclusions: Phenylephrine in an infusion dose of $50 \mu \mathrm{g} / \mathrm{min}$ gives stable haemodynamics with good neonatal outcome.
\end{abstract}

Keywords: Phenylephrine; spinal anaesthesia; caesarean section

\section{Introduction}

Spinal anaesthesia is a commonly used anaesthetic technique for caesarean delivery. But, it is frequently associated with hypotension, which can have detrimental effects on the mother and neonate. ${ }^{1}$ Till recently, ephedrine was considered the vasopressor of choice for management of hypotension induced by spinal anaesthesia. $^{2}$ Studies in the last decade have shown that fetal acid-base status is better preserved with phenylephrine., Although a continuous infusion of prophylactic phenylephrine might be more effective in maintaining baseline systolic pressures, reports have expressed concerns over the large doses of phenylephrine required to maintain blood pressure resulting in reflex bradycardia. ${ }^{5}$ The optimal dosing regimen for administration of phenylephrine infusion is undetermined and current practice includes both phenylephrine infusion and intermittent bolus administration. ${ }^{6}$ In this background a study was undertaken to determine the optimal dose of prophylactic phenylephrine infusion and its consequences, neonatal umbilical cord blood acid base status and neonatal APGAR score.

\section{Method}

Institutional ethics committee approval and written informed consent was obtained from all parturients included in the study. One hundred parturients of American Society of Anaesthesiologists (ASA) physical status I or II scheduled for elective caesarean section with term singleton gestation, body weight $40-70 \mathrm{~kg}$, height $145-165 \mathrm{~cm}$ were included. Parturients with pregnancy induced hypertension or preeclampsia, cardiovascular or cerebro vascular diseases, caesarean deliveries done for nonreassuring foetal status were excluded from the study.

All parturients were pre medicated with oral ranitidine $150 \mathrm{mg}$ and metoclopramide $10 \mathrm{mg}$ the night before and the morning of surgery. Adequate fasting guidelines were ensured. The parturients were randomly allocated into one of four groups of 25 each by picking lots. Phenylephrine was infused for each group as follows. Group P25 at $25 \mu \mathrm{g} / \mathrm{min}$, Group P50 at $50 \mu \mathrm{g} / \mathrm{min}$, Group P75 at $75 \mu \mathrm{g} / \mathrm{min}$ and Group $\mathrm{P} 100$ at $100 \mu \mathrm{g} / \mathrm{min}$.

Standard monitoring was established once the parturient was shifted inside the operation room. 
Mean arterial pressure was recorded and the upper and lower limits (20\% above and below the baseline) were calculated. After securing an intravenous access, lactated Ringer's solution was administered at a rate of $10 \mathrm{ml} / \mathrm{kg}$ rounded off to the nearest $50 \mathrm{ml}$.

Spinal anaesthesia was administered with 25gauge Quincke type spinal needle using $2 \mathrm{ml}$ of $0.5 \%$ Bupivacaine heavy. The level of block obtained at the end of 5 minutes was noted and the level re-assessed every 5 minutes until the level stabilized. Parturients were excluded from the study if the level ascended higher than T4 level. Parturients whose block were inadequate and required conversion to general anaesthesia were also excluded from the study.

Phenylephrine solutions for infusion were prepared by anaesthesia junior resident for Group P25, P50, P75 and P100 in concentrations of $25 \mu \mathrm{g} / \mathrm{ml}, 50 \mu \mathrm{g} / \mathrm{ml}, 75 \mu \mathrm{g} / \mathrm{ml}$ and $100 \mu \mathrm{g} / \mathrm{ml}$ respectively and the infusion was started with an infusion pump for the respective groups at a rate of $1 \mathrm{ml} /$ minute immediately after administration of the subarachnoid block.

Maternal blood pressure and heart rate was recorded every minute. Hypotension was defined as fall in mean blood pressure of $20 \%$ or more from the baseline and was treated with 50 $\mu \mathrm{g}$ bolus dose of phenylephrine.

Maternal bradycardia was defined as heart rate of less than 50 beats per minute. Bradycardia associated with hypotension was treated with i.v. atropine $0.6 \mathrm{mg}$.

The number of parturients who experienced any episodes of hypotension (mean blood pressure < $20 \%$ below baseline), reactive hypertension (mean blood pressure $>20 \%$ above baseline) and bradycardia were recorded in each group. Infusions of study drugs was stopped if the blood pressure rose to $20 \%$ above baseline values and restarted after one minute if required.

The incidence and severity of nausea and vomiting was noted in all parturients and scored as 0- No nausea or vomiting, 1-Nausea present but no vomiting, 2-Nausea present associated with vomiting. The time of administration of spinal anaesthesia (T1), the skin incision time (T2), the uterine incision time (T3) and the time the baby was delivered (T4) was noted.

Oxytocin infusion was started for the mother immediately after delivery of the baby.
The paediatrician in attendance at delivery assessed the Apgar score at 1 and 5 minutes. Neonatal outcome was assessed by measuring base excess from umbilical arterial blood samples.

The study ended soon after delivery of the baby. Further administration of these infusions or bolus medications was at the discretion of the anaesthesiologist in charge of the case.

\section{Results}

Descriptive and inferential statistical analysis has been carried out in the present study. Results on continuous measurements are presented on Mean \pm SD (Min-Max) and results on categorical measurements are presented in Number (\%). Significance is assessed at 5\% level of significance. Analysis of variance (ANOVA) has been used to find the significance of study parameters between three or more groups of parturients.

Chi-square/ Fisher Exact test has been used to find the significance of study parameters on categorical scale between two or more groups.

A total of one hundred parturients presenting for elective caesarean section under spinal anaesthesia were studied. All the parturients completed the study without any complications.

The demographic, surgical and anaesthetic characteristics of the parturients in four groups were comparable without any statistical difference. (Table 1) The baseline haemodynamic variables like heart rate, systolic, diastolic and mean blood pressure are comparable without significant difference. (Table 2)

Table 1: Demographic, anaesthetic and surgical characteristics

\begin{tabular}{|l|l|l|l|l|l|}
\hline Characteristics & $\begin{array}{l}\text { Group 25 } \\
(\mathrm{n}=25)\end{array}$ & $\begin{array}{l}\text { Group 50 } \\
(\mathrm{n}=25)\end{array}$ & $\begin{array}{l}\text { Group 75 } \\
(\mathrm{n}=25)\end{array}$ & $\begin{array}{l}\text { Group 100 } \\
(\mathrm{n}=25)\end{array}$ & $\begin{array}{l}\mathrm{p} \\
\text { value }\end{array}$ \\
\hline $\begin{array}{l}\text { Age (years) } \\
\text { mean (SD) }\end{array}$ & $24.8(3.0)$ & $26.8(3.6)$ & $25.9(3.1)$ & $27.3(2.8)$ & 0.062 \\
\hline $\begin{array}{l}\text { Height (cm) } \\
\text { mean (SD) }\end{array}$ & $155.6(5.4)$ & $154.4(5.7)$ & $\begin{array}{l}157.2 \\
(7.1)\end{array}$ & $160.0(5.4)$ & 0.121 \\
\hline $\begin{array}{l}\text { Weight (kg) } \\
\text { mean (SD) }\end{array}$ & $60.9(6.1)$ & $60.6(5.8)$ & $62.4(7.3)$ & $64.6(4.7)$ & 0.134 \\
\hline $\begin{array}{l}\text { Block height } \\
\text { (dermatome } \\
\text { level) } \\
\text { median( } \\
\text { interquartile } \\
\text { range) }\end{array}$ & $\begin{array}{l}\mathrm{T} 6 \\
\text { (T4-T6) }\end{array}$ & $\begin{array}{l}\mathrm{T} 6 \\
(\mathrm{~T} 4-\mathrm{T} 6)\end{array}$ & $\begin{array}{l}\mathrm{T} 6 \\
(\mathrm{~T} 4-\mathrm{T} 6)\end{array}$ & $\begin{array}{l}\mathrm{T} 4 \\
(\mathrm{~T} 4-\mathrm{T} 6)\end{array}$ & \\
\hline $\begin{array}{l}\text { R preload } \\
\text { (ml) } \\
\text { mean (SD) }\end{array}$ & $616.5 \pm 64.2$ & $617.5 \pm 63.4$ & $633.5 \pm 67$ & $657.5 \pm 46.6$ & 0.124 \\
\hline $\begin{array}{l}\text { Induction to } \\
\text { delivery time } \\
\text { (min) } \\
\text { mean (SD) }\end{array}$ & $5.85 \pm 1.98$ & $5.65 \pm 1.93$ & $5.90 \pm 2.05$ & $5.90 \pm 1.68$ & 0.100 \\
\hline $\begin{array}{l}\text { Incision to } \\
\text { delivery time } \\
\text { (min) } \\
\text { mean (SD) }\end{array}$ & $2.45 \pm 1.85$ & $2.00 \pm 1.22$ & $1.60 \pm 0.68$ & $1.75 \pm 0.91$ & 0.156 \\
\hline
\end{tabular}


Table 2: Baseline haemodynamic variables

\begin{tabular}{|l|l|l|l|l|l|}
\hline Characteristics & $\begin{array}{l}\text { Group } \\
25 \\
(\mathrm{n}=25)\end{array}$ & $\begin{array}{l}\text { Group } \\
50 \\
(\mathrm{n}=25)\end{array}$ & $\begin{array}{l}\text { Group } \\
(\mathrm{n}=25)\end{array}$ & $\begin{array}{l}\text { Group } \\
100 \\
(\mathrm{n}=25)\end{array}$ & $\begin{array}{l}\mathrm{p} \\
\text { value }\end{array}$ \\
\hline Heart rate $(\mathrm{b} / \mathrm{min})$ & 97 & 91 & 94 & 87 & 0.064 \\
\hline Systolic BP $(\mathrm{mmHg})$ & 122 & 118 & 114 & 119 & 0.269 \\
\hline $\begin{array}{l}\text { Diastolic BP } \\
(\mathrm{mmHg})\end{array}$ & 77 & 73 & 76 & 74 & 0.468 \\
\hline Mean BP $(\mathrm{mmHg})$ & 91 & 89 & 91 & 86 & 0.201 \\
\hline
\end{tabular}

$25 \%$ subjects in the group who received $25 \mu \mathrm{g} / \mathrm{kg} / \mathrm{min}$ of phenylephrine infusion had hypotension with mean arterial pressure less than $20 \%$ baseline requiring additional bolus doses of phenylephrine which was statistically significant $(\mathrm{p}<0.05)$. Six parturients in group 25 had to receive a bolus dose of a vasopressor to maintain blood pressure in normal range in spite of continuous infusion of phenylephrine infusion which was statistically significant $(\mathrm{p}<0.003)$.

None of the parturients in group 25 had hypertension, where as $5 \%$ of parturients in group 50, $40 \%$ of parturients in group 75 and 55 $\%$ of parturients in group100 had hypertension with mean arterial pressure more than $20 \%$ baseline requiring the infusion of phenylephrine to be stopped at least once. This was statistically significant $(\mathrm{p}=0.001)$. No parturients in group 25 and group 50 had reactionary bradycardia. $30 \%$ of parturients in group 75 and $45 \%$ of parturients in group 100 had bradycardia requiring atropine administration. None of the parturients in any group had nausea or vomiting. (Table 3)

Table 3: Response to different doses of phenylephrine infusion

\begin{tabular}{|c|c|c|c|c|c|}
\hline Characteristics & $\begin{array}{l}\text { Group } \\
25 \\
(\mathrm{n}=25)\end{array}$ & $\begin{array}{l}\text { Group } \\
50 \\
(\mathrm{n}=25) \\
\end{array}$ & $\begin{array}{l}\text { Group } \\
75 \\
(\mathrm{n}=25) \\
\end{array}$ & $\begin{array}{l}\text { Group } \\
100 \\
(n=25) \\
\end{array}$ & $p$ value \\
\hline $\begin{array}{l}\text { Incidence of hypotension } \\
(\%) \\
\text { MAP } 20 \% \text { less than } \\
\text { baseline }\end{array}$ & 25 & - & - & - & $0.003^{* *}$ \\
\hline $\begin{array}{l}\text { Incidence of hypertension } \\
(\%) \\
\text { MAP } 20 \% \text { more than } \\
\text { baseline }\end{array}$ & - & 5 & 40 & 55 & $0.001^{* *}$ \\
\hline Incidence of bradycardia & - & - & 30 & 45 & $0.001^{* \star}$ \\
\hline $\begin{array}{l}\text { Number of mother's who } \\
\text { received atleast one } \\
\text { rescue dose of atropine }\end{array}$ & 1 & - & 6 & 9 & $0.001^{* \star}$ \\
\hline $\begin{array}{l}\text { Bolus doses of } \\
\text { vasopressor used }\end{array}$ & 6 & - & - & - & $0.003^{* *}$ \\
\hline $\begin{array}{l}\text { Infusion of phenylephrine } \\
\text { stopped atleast once }(\%)\end{array}$ & 0 & 5 & 40 & 55 & $0.001^{* *}$ \\
\hline $\begin{array}{l}\text { Incidence of nausea and } \\
\text { vomiting }\end{array}$ & - & - & - & - & - \\
\hline
\end{tabular}

* Moderately significant ( $\mathrm{p}$ value: $0.01<\mathrm{p} \leq$ $0.05) * *$ Strongly significant ( $\mathrm{p}$ value: $\mathrm{p} \leq 0.01$ )
Serial analysis of haemodynamic changes showed that heart rate variation over time were less significant in group 25 , group 50 and group 75 as compared to group 100 . There was a significant decrease in heart rate in group 100 at $4^{\text {th }}$ minute compared to baseline $(\mathrm{p}<0.001)$. Also group 100 showed a significant increase in heart rate towards the end as compared to the other groups $(\mathrm{p}<0.005)$. (Figure 1 )

Figure 1: Heart rate variability between the groups

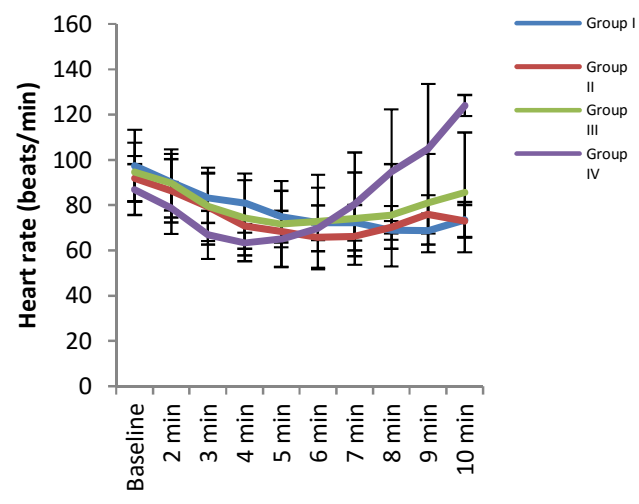

The variation in systolic blood pressure and mean blood pressure over time was more significant in group 100 as compared to the other groups from 3 min onwards $(\mathrm{p}<0.001)$. (Figure 2)

Figure 2: Systolic blood pressure response between the groups

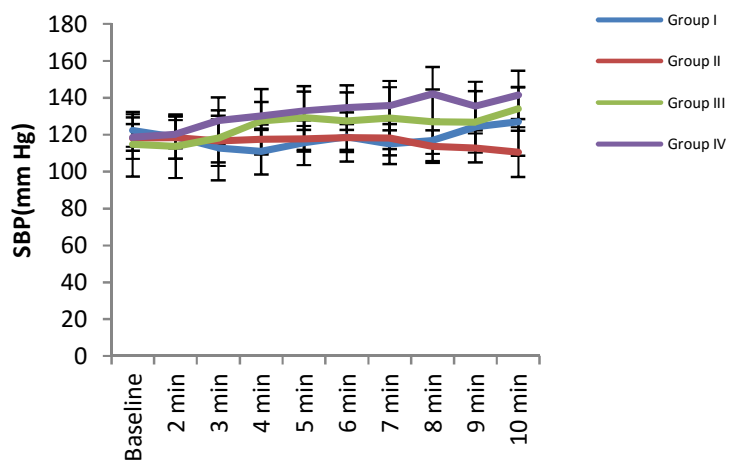

The base excess and the APGAR score of the neonates at one minute and five minute interval were comparable between the four groups. (Table 4) 
Table 4: Neonatal characteristics between the groups

\begin{tabular}{|l|l|l|l|l|l|}
\hline $\begin{array}{l}\text { Characteristi } \\
\text { cs }\end{array}$ & $\begin{array}{l}\text { Group } \\
25 \\
(\mathrm{n}=25)\end{array}$ & $\begin{array}{l}\text { Group } \\
50 \\
(\mathrm{n}=25)\end{array}$ & $\begin{array}{l}\text { Group75 } \\
(\mathrm{n}=25)\end{array}$ & $\begin{array}{l}\text { Group } \\
100 \\
(\mathrm{n}=25)\end{array}$ & $\begin{array}{l}\mathrm{p} \\
\text { valu } \\
\mathrm{e}\end{array}$ \\
\hline $\begin{array}{l}\text { Base excess } \\
\text { (mean } \pm \text { SD) }\end{array}$ & $\begin{array}{l}2.50 \pm 0.8 \\
9\end{array}$ & $\begin{array}{l}2.75 \pm 0.9 \\
1\end{array}$ & $\begin{array}{l}- \\
2.65 \pm 0.9 \\
3\end{array}$ & $\begin{array}{l}- \\
2.70 \pm 0.8 \\
0\end{array}$ & $\begin{array}{l}0.82 \\
7\end{array}$ \\
\hline $\begin{array}{l}\text { APGAR } \\
1 \text { min } \\
\text { median } \\
\text { (range) }\end{array}$ & $\begin{array}{l}(7-10) \\
\begin{array}{l}\text { APGAR } \\
5 \text { min } \\
\text { median } \\
\text { (range) }\end{array}\end{array}$ & $\begin{array}{l}7 \\
(6-8)\end{array}$ & $\begin{array}{l}7.0 \\
(7-8)\end{array}$ & $\begin{array}{l}7.0 \\
(7-8)\end{array}$ & $\begin{array}{l}0.12 \\
2\end{array}$ \\
\hline
\end{tabular}

\section{Discussion}

In our study we observed that phenylephrine infusion in a dose of $50 \mu \mathrm{g} / \mathrm{min}$ followed by crystalloid co-loading provides stable haemodynamics during spinal anaesthesia for caesarean delivery. Crystalloid preloading as a sole measure before spinal anaesthesia for caesarean delivery is not effective in preventing hypotension. $^{7}$ This may be due to rapid redistribution and stimulation of atrial natriuretic peptide secretion that lead to peripheral vasodilatation and dieresis. ${ }^{8}$ Hence fluid coloading during administration of spinal anaesthesia seems to be more rational approach. ${ }^{9}$ We chose to give phenylephrine as an infusion as it has shown to be associated with a decreased incidence of hypotension as compared to phenylephrine boluses. ${ }^{10}$ The $\mathrm{ED}_{90}$ dose of phenylephrine required to treat spinal anaesthesia induced hypotension in caesarean delivery is approximately $150 \mu \mathrm{g}$ as determined by George et al. ${ }^{11}$ In our study a maximum infusion dose of $100 \mu \mathrm{g} / \mathrm{min}$ was chosen. Similar dose was used by several other investigators. ${ }^{12}$, 13,14

Fixed dose of phenylephrine infusion rates were chosen with a target haemodynamic goal and on/off method to keep the study simple and reproducible. This is partly a limitation of our study as it did not eliminate hypotension or hypertension completely. Group which received lower infusion rates had hypotension requiring additional boluses of phenylephrine whereas the subjects in group which received $100 \mu \mathrm{g} / \mathrm{min}$ had hypertension requiring the infusion to be stopped and restarted. A more flexible protocol that did not completely stop the infusion or allowed small boluses to be given when infusion was restarted may have further reduced or totally eliminated hypotension or hypertensive episodes. This argument is similar to Ngan Kee et al in their study on prophylactic phenylephrine infusion for preventing hypotension during spinal anaesthesia for caesarean delivery. ${ }^{12}$ In another study, Ngan Kee et al reported that a closed-loop variable rate algorithm provided tighter and more accurate blood pressure control compared to the manual on/off technique, but with no difference in maternal and neonatal outcomes. ${ }^{15}$

We observed in our study the incidence of reactive hypertension requiring the infusion to be stopped was higher in the 75 and $100 \mu \mathrm{g} / \mathrm{min}$ infusion regimens. Reactive hypertension can be a problem and is a concern with prophylactic phenylephrine infusions. ${ }^{16}$ Ideally, the infusion should be stopped before reactive hypertension occurs. Unlike in the study done by Allen TK ${ }^{4}$, we did not notice hypertension in infusion rates of $25 \mu \mathrm{g} / \mathrm{min}$ and $50 \mu \mathrm{g} / \mathrm{min}$. The maternal heart rate was slower in the group which received phenylephrine infusions at $75 \mu \mathrm{g} / \mathrm{min}$ and $100 \mu \mathrm{g} / \mathrm{min}$. However all of these cases were not associated with hypotension. The likely mechanism can be explained by baroreceptor reflex. Studies have consistently reported slower heart rate with phenylephrine than with ephedrine..$^{10,17}$

Comparison of different phenylephrine infusion rates demonstrates dose dependent reductions in heart rate. Bradycardia occurring during administration of a prophylactic phenylephrine infusion should be managed by reducing the rate or stopping the infusion unless accompanied by hypotension. Administration of atropine to treat bradycardia in absence of hypotension results in significant hypertension. Another limitation of our study is inability to monitor the cardiac output. Phenylephrine has been shown in several previous studies to reduce cardiac output. ${ }^{18,19}$ Initiation of phenylephrine infusion is usually associated with an increase on systemic vascular resistance, a consequent reduction in stroke volume and cardiac output. In subjects receiving phenylephrine infusions at 25,50 , and $100 \mu \mathrm{g} / \mathrm{min}$ after spinal anaesthesia, there was a significant dose related reduction in heart rate and cardiac output measured using supra-sternal Doppler for $20 \mathrm{~min}$ after spinal anaesthesia. ${ }^{19}$ 
Neonatal assessments were performed in most studies using Apgar scores and umbilical cord blood gas and $\mathrm{pH}$. Low Apgar scores alone are not sufficient evidence of hypoxia and poor correlation are observed between Apgar scores and cord blood $\mathrm{pH}^{20}$. In our study there was no difference in umbilical cord base excess values among the groups despite a higher incidence of maternal pre- delivery hypotension in group receiving $25 \mu \mathrm{g} / \mathrm{min}$ infusions. There was no difference in Apgar score between the four groups and all neonates had good Apgar score.

To conclude, the optimal dose of prophylactic phenylephrine infusion for prevention of hypotension in parturients receiving spinal anaesthesia for elective caesarean delivery is $50 \mu \mathrm{g} / \mathrm{min}$ and at that dose it provides stable maternal haemodynamics and normal neonatal outcome.

\section{References}

1. Habib AS. A review of the impact of phenylephrine administration on maternal haemodynamics and maternal and neonatal outcomes in women undergoing cesarean delivery under spinal anesthesia. AnesthAnalg 2012; 114:377-90

http://dx.doi.org/10.1213/ANE.0b013e3182373a $\underline{3 e}$

PMid:22104076

2. James FM, Greiss FC. Kemp RA. An evaluation of vasopressor therapy for maternal hypotension during spinal anesthesia. Anesthesiology 1970;33:25-34

http://dx.doi.org/10.1097/00000542-197007000$\underline{00010}$

3. Lee A, Ngan Kee WD, Gin T. A quantitative, systematic review of randomized controlled trails of ephedrine versus phenylephrine for the management of hypotension during spinal anesthesia for caesarean delivery. AnesthAnalg 2002;94:920-6

http://dx.doi.org/10.1097/00000539-200204000$\underline{00028}$

PMid: 11916798

4. Allen TK, Muir HA, George RB, Habib AS. A survey of the management of spinal induced hypotension for scheduled caesarean delivery. Int J Obstet Anesth 2009;18:356-61 http://dx.doi.org/10.1016/j.ijoa.2009.03.014 PMid:19734039

5. Gupta S. Vasopressors and tight control of maternal blood pressure during caesarean delivery. A rocky alliance. J AnaesthesiolClinPharmacol 2013;29:1-3 http://dx.doi.org/10.4103/0970-9185.105777

PMid:23495264 PMCid:PMC3590510

6. Doherty A, Ohashi Y, Downey K, Carvalho JCA. Phenylephrine infusion versus bolus regimens during cesarean delivery under spinal anesthesia: A double blind randomized clinical trial to assess hemodynamic changes. AnesthAnalg 2012;115:1343-50 http://dx.doi.org/10.1213/ANE.0b013e31826ac3 $\underline{\mathrm{db}}$ PMid:23011562

7. Husaini S Russell I. Volume preload: lack of effect in the prevention of spinal induced hypotension at caesarean section. Int $\mathbf{J}$ ObstetAnesth 1998;7:76

http://dx.doi.org/10.1016/S0959289X(98)90001-2

8. Pouta A, Karinen J, Vuoltennnaho O Laatikainen T. Effect of intravenous fluid preload on vasoactive peptide secretion during cesarean section under spinal anaesthesia. Anaesthesia 1996;51:128

http://dx.doi.org/10.1111/j.13652044.1996.tb07698.x

PMid:8779366

9. Loughrey J, Yao N, Datta S, Pian-Smith M Tsen L. Hemodynamic effects of spinal anaesthesia and simultaneous intravenous bolus of combined phenylephrine and ephedrine versus ephedrine for cesarean delivery. Int $\mathrm{J}$ ObstetAnesth 2005; 14:43

http://dx.doi.org/10.1016/j.ijoa.2004.07.011 PMid: 15627538

10. Thomas DG, Robson SC, Redfern N, Hughes D, Boys RJ. Randomized trial of bolus phenylephrine or ephedrine for maintenance of arterial pressure during spinal anaesthesia for Caesarean section. Br J Anaesth 1996;76:61-5 http://dx.doi.org/10.1093/bja/76.1.61 PMid:8672382

11. George RB, McKeen D, Columb MO, Habi AS. Up-down determination of the $90 \%$ effective dose of phenylephrine for the treatment of spinal anesthesia induced hypotension in parturients undergoing cesarean delivery. AnesthAnalg 2010;110: $154-8$ http://dx.doi.org/10.1213/ANE.0b013e3181c30b 72

PMid: 19910625

12. Ngan Kee WD, Khaw KS, Ng FF, Lee BB. Prophylactic phenylephrine infusion for preventing hypotension during spinal anesthesia for cesarean delivery. AnesthAnalg 2004;98:81521

http://dx.doi.org/10.1213/01.ANE.0000099782.7 $\underline{8002.30}$

13. Ngan Kee WD, Khaw KS, Ng FF. Comparison of phenylephrine infusion regimens for maintaining maternal blood pressure during 
spinal anaesthesia for caesarean section.Br J Anaesth2004;92:469-74 http://dx.doi.org/10.1093/bja/aeh088 PMid:14977792

14. Ngan Kee WD, Lee A, Khaw $\mathrm{KS}$, Ng FF, Karmakar MK, Gin T. A randomized double blinded comparison of phenylephrine and ephedrine infusion combinations to maintain blood pressure during spinal anaesthesia for caesarean delivery: The effects on foetal acid base status and hemodynamic control. AnesthAnalg 2008;107;1295-1302 http://dx.doi.org/10.1213/ane.0b013e31818065b $\underline{\mathrm{c}}$ PMid: 18806043

15. Ngan Kee WD, Khaw KS, Tam YH, Ng FF. Comparison of closed loop feedback computer controlled and manual controlled phenylephrine infusions during spinal anesthesia for cesarean section. Int J Obstet Anesth 2011;20:S17

16. Beilin Y. The treatment should not be worse than the disease. Anesthesiology 2006;104:1348-9 http://dx.doi.org/10.1097/00000542-200606000$\underline{00046}$

PMid:16732121

17. Cooper DW, Carpenter M, Mowbray P, et al. Fetal and maternal effects of phenylephrine and ephedrine during spinal anesthesia for caesarean delivery. Anesthesiology 2002;97:1582-90 http://dx.doi.org/10.1097/00000542-200212000$\underline{00034}$

PMid:12459688

18. Dyer RA, Reed AR, van Dyk D, Arcache MJ, Hodges O, Lombard CJ, Greenwood J, James MF. Hemodynamic effects of ephedrine, phenylephrine and the co administration of phenylephrine with oxytocin during spinal anesthesia for elective cesarean delivery. Anesthesiology2009;111:753-65. http://dx.doi.org/10.1097/ALN.0b013e3181b437 $\underline{\mathrm{e} 0}$ PMid: 19741494

19. Langesaeter E, Rosseland LA, Stubhaug A. Continuous invasive blood pressure and cardiac output monitoring during cesarean delivery: a randomized double-blind comparison of low dose versus high dose spinal anesthesia with intravenous phenylephrine or placebo infusion. Anesthesiology2008;109:856-63 http://dx.doi.org/10.1097/ALN.0b013e31818a40 1f PMid: 18946298

20. ACOG committee opinion. Use and abuse of Apgar score. Number 174-July 1996.Int J Gynaecol Obstet 1996;54:303-5

PMid:8889640 